\title{
Analysis of Cu Diffusion in ZnTe- Based Contacts for Thin-Film CdS/CdTe Solar Cells
}

C. Narayanswamy

Department of Physics \& Astronomy

University of Toledo

T.A. Gessert and S.E. Asher

National Renewable Energy Laboratory

Presented at the National Center for

Photovoltaics Program Review Meeting

Denver, Colorado

September 8-11, 1998

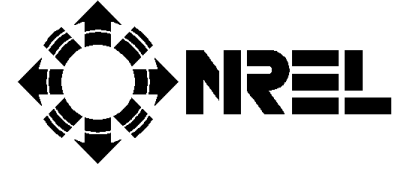

National Renewable Energy Laboratory 1617 Cole Boulevard Golden, Colorado 80401-3393

A national laboratory of the U.S. Department of Energy Managed by Midwest Research Institute for the U.S. Department of Energy under contract No. DE-AC36-83CH10093

Work performed under task number PV904201

October 1998 


\begin{abstract}
NOTICE
This report was prepared as an account of work sponsored by an agency of the United States government. Neither the United States government nor any agency thereof, nor any of their employees, makes any warranty, express or implied, or assumes any legal liability or responsibility for the accuracy, completeness, or usefulness of any information, apparatus, product, or process disclosed, or represents that its use would not infringe privately owned rights. Reference herein to any specific commercial product, process, or service by trade name, trademark, manufacturer, or otherwise does not necessarily constitute or imply its endorsement, recommendation, or favoring by the United States government or any agency thereof. The views and opinions of authors expressed herein do not necessarily state or reflect those of the United States government or any agency thereof.
\end{abstract}

Available to DOE and DOE contractors from:

Office of Scientific and Technical Information (OSTI)

P.O. Box 62

Oak Ridge, TN 37831

Prices available by calling 423-576-8401

Available to the public from:

National Technical Information Service (NTIS)

U.S. Department of Commerce

5285 Port Royal Road

Springfield, VA 22161

703-605-6000 or 800-553-6847

or

DOE Information Bridge

http://www.doe.gov/bridge/home.html 


\title{
Analysis of Cu Diffusion in ZnTe-Based Contacts for Thin-Film CdS/CdTe Solar Cells
}

\author{
C. Narayanswamy, * T.A. Gessert, and S.E. Asher \\ National Renewable Energy Laboratory (NREL), Golden, CO 80401 \\ *Department of Physics \& Astronomy, University of Toledo, Toledo, OH 43606
}

\begin{abstract}
Ohmic contacts to thin-film CdS/CdTe photovoltaic devices have been formed using a two-layer contact interface of undoped $\mathrm{ZnTe}(\mathrm{ZnTe})$ and $\mathrm{Cu}$-doped $\mathrm{ZnTe}(\mathrm{ZnTe}: \mathrm{Cu})$, followed by $\mathrm{Ni}$ or Ti as an outer metallization. Secondary ion mass spectroscopy (SIMS) is used to study $\mathrm{Cu}$ diffusion within this back-contact structure, and also, to monitor $\mathrm{Cu}$ diffusion from the contact into the CdTe. When Ni metallization is used, the $\mathrm{ZnTe}: \mathrm{Cu}$ layer becomes increasingly depleted of $\mathrm{Cu}$, and $\mathrm{Ni}$ diffusion into the $\mathrm{ZnTe}: \mathrm{Cu}$ increases as the contact deposition temperature increases from $100^{\circ} \mathrm{C}$ to $300^{\circ} \mathrm{C}$. $\mathrm{Cu}$ depletion is not observed when $\mathrm{Ni}$ is replaced with $\mathrm{Ti}$. Diffusion of $\mathrm{Cu}$ from the $\mathrm{ZnTe}: \mathrm{Cu}$ layer into the $\mathrm{ZnTe}$ layer also increases with contact deposition temperature, and produces a buildup of $\mathrm{Cu}$ at the $\mathrm{ZnTe} / \mathrm{CdTe}$ interface. High-mass resolution SIMS indicates that, although $\mathrm{Cu}$ levels in the $\mathrm{CdTe}$ remain low, $\mathrm{Cu}$ diffusion from the contact proceeds into the $\mathrm{CdTe}$ layer and toward the $\mathrm{CdTe} / \mathrm{CdS}$ junction region.
\end{abstract}

\section{INTRODUCTION}

Photovoltaic (PV) solar cells based on thin-film CdTe are leading candidates for large-scale manufacturing (1). However, to realize the full potential of this technology, mass-production methods to produce stable and low-resistance electrical contacts to p$\mathrm{CdTe}$ must be demonstrated. Forming low-resistance ohmic contacts to p-type CdTe is difficult for several reasons. First, no metals have a work function large enough to produce an ohmic contact to $\mathrm{p}-\mathrm{CdTe}(2)$. Moreover, studies suggest that the surface Fermi level is pinned, limiting the extent to which CdTe will obey Mott-Schottky theory. Finally, acceptor compensation in p-CdTe results in low doping efficiency, limiting the effectiveness of contacts that must rely on quantum-mechanical tunneling. Even though these limitations present considerable obstacles to forming ohmic contacts, reasonable cell efficiencies have been obtained using a variety of contacts such as $\mathrm{Au} / \mathrm{Cu}$ metal films (3) or graphite paste doped with $\mathrm{HgTe}$ and $\mathrm{Cu}$ (4).

Another contacting technique incorporates an interfacial layer between the p-type $\mathrm{CdTe}$ and a metal contact. The interfacial layer must provide both a negligibly small valence-band discontinuity with $\mathrm{p}$-CdTe and enable high p-type doping to facilitate low-resistance quantum-mechanical tunneling. ZnTe is a recognized candidate for such an interfacial layer. Studies on crystalline materials have indicated small valence-band offsets for $\mathrm{ZnTe} / \mathrm{CdTe}(5)$, and p-type doping of polycrystalline $\mathrm{ZnTe}$ with $\mathrm{Cu}$ has been demonstrated to $>10^{18} \mathrm{~cm}^{-3}(6)$. Although ZnTe contacts have demonstrated reasonable success and stability (7), the use of $\mathrm{Cu}$ in back contacts of $\mathrm{CdTe} / \mathrm{CdS}$ thinfilm devices has been a subject of considerable debate. $\mathrm{Cu}$ has been linked to enhanced device performance by reducing series resistance and increasing open-circuit voltage. 
However, $\mathrm{Cu}$ is also known to be a fast diffuser in most materials and will diffuse even more quickly along the polycrystalline grain boundaries. For these reasons, $\mathrm{Cu}-$ containing contacts have been associated with various types of instability in CdTe devices (8). In the following study, SIMS is used to assess variations in $\mathrm{Cu}$ concentration in the $\mathrm{ZnTe}$ and CdTe layers. These results are linked to deviceperformance characteristics typically observed when the ZnTe bilayer contact is used.

\section{EXPERIMENTAL}

The $\mathrm{CdS} / \mathrm{CdTe}$ devices used for this study were grown using close-spaced sublimation (CSS) on 4.5-mm-thick soda-lime glass at Solar Cells Inc. (SCI, Toledo, $\mathrm{OH})$. All the samples were treated with $\mathrm{CdCl}_{2}$ using a wet process at SCI. Except where noted, the CdTe surfaces were chemically etched with $1 \mathrm{HNO}_{3}: 85 \mathrm{H}_{3} \mathrm{PO}_{4}: 33$ $\mathrm{H}_{2} \mathrm{O}$, for $15 \mathrm{~s}$ (NP etch), and the deposition temperature was maintained at $\sim 300^{\circ} \mathrm{C}$. $\mathrm{ZnTe}$ and $\mathrm{ZnTe} \mathrm{Cu}$ contact interface layers were deposited sequentially using r.f. magnetron sputtering. The outer metallization was deposited using d.c. magnetron sputtering to a thickness of $\sim 0.5 \mu \mathrm{m}$. Additional experimental details are provided elsewhere (7). Two different contact metals, $\mathrm{Ni}$ and $\mathrm{Ti}$, were studied. Following contact deposition, several $0.25-\mathrm{cm}^{2}$ devices were fabricated on each substrate using photolithography and chemical etching. Ni-metallized devices were patterned using a $39 \% \mathrm{FeCl}_{3}$ aqueous solution to remove the unwanted $\mathrm{Ni}, \mathrm{ZnTe}: \mathrm{Cu}, \mathrm{ZnTe}$, and $\mathrm{CdTe}$ layers in one $\sim 3$-min etching step. For Ti-metallized devices, the Ti layer was removed first with "TFT Ti Etchant" (Transene Co., Inc.), followed by the $39 \% \mathrm{FeCl}_{3}$ solution to remove the $\mathrm{ZnTe}, \mathrm{ZnTe}: \mathrm{Cu}$, and CdTe layers. Devices were characterized using light current-voltage (I-V) measurements prior to SIMS analysis.

Earlier SIMS analysis indicated that non-uniform sputtering of the contact metallization reduced depth resolution significantly in the underlying ZnTe and CdTe layers. To avoid this problem, the $\mathrm{Ni}$ and $\mathrm{Ti}$ metallizations were removed prior to SIMS analysis. The low adhesion of the Ni to the $\mathrm{ZnTe}: \mathrm{Cu}$ allowed its removal using Scotch tape. The adhesion of $\mathrm{Ti}$ to $\mathrm{ZnTe}: \mathrm{Cu}$ is significantly greater, and its removal required the use of the previously noted TFT chemical etchant. Following metal removal, the exposed sample surfaces were cleaned with acetone and methanol, and dried using $\mathrm{N}_{2}$. SIMS depth profiling was performed from the contacted side of the devices with a Cameca IMS-5F unit using $60 \mathrm{nA}, 10 \mathrm{keV} \mathrm{Cs}^{+}$, a primary ion-beam impact energy of $5.5 \mathrm{keV}$, an incidence angle of $42^{\circ}$, and tuned for a mass resolution $(\mathrm{M} / \Delta \mathrm{M})$ of $\sim 300$. The beam was rastered over a $250-\mu \mathrm{m}^{2}$ (crater) area. The effect of crater edges on depth resolution was limited by collecting positive secondary ions normal to the sample surface, and only from a central $\sim 35-\mu \mathrm{m}$-diameter region of the crater. The signal was limited further by a $50 \%$ electronic gate. For high-mass resolution analysis, $12.5 \mathrm{keV} \mathrm{O}_{2}^{+}$was used as the primary ion $(8 \mathrm{keV}$ impact energy, $\left.39^{\circ}\right)$, and the instrument was tuned for a mass resolution $(\mathrm{M} / \Delta \mathrm{M})$ of $\sim 4000$. 


\section{RESULTS AND DISCUSSION}

All SIMS profiles in the following figures have been scaled to an average of the Te signal within the CdTe layer. Previous studies have shown that the Te concentration in r.f. sputtered $\mathrm{ZnTe}: \mathrm{Cu}$ is maintained at $51 \pm 1$ at. $\%$ for $\mathrm{Cu}$ concentrations up to $\sim 8$ at.\% (9). Although small changes in the Te concentration with increasing substrate temperature have been observed, the Te concentration for $\mathrm{ZnTe}: \mathrm{Cu}$ films containing $\sim 5-6$ at. $\% \mathrm{Cu}$ remains at $51 \pm 1$ at.\% within the substrate temperature range investigated here $\left(100^{\circ}-300^{\circ} \mathrm{C}\right)(6)$. The detection sensitivity of SIMS can also vary depending on the matrix from which the element is sputtered. Although complications related to the outer metallization have been eliminated (by removing the metal prior to SIMS analysis), a matrix difference remains between sputter-deposited ZnTe and CSSdeposited CdTe. Without information on the $\mathrm{Cd} / \mathrm{Te}$ ratio or sputter yield of $\mathrm{Cu}$ in $\mathrm{CSS}$ CdTe relative to sputtered $\mathrm{ZnTe}$, we have assumed that the effect on the $\mathrm{Cu}$ ion yield between ZnTe and CdTe is small.

The approximate location of interfaces between $\mathrm{ZnTe}: \mathrm{Cu} / \mathrm{ZnTe}$ and $\mathrm{ZnTe} / \mathrm{CdTe}$ layers are indicated on the figures. Because the as-received surfaces of these devices are rough (surface roughness $\sim 200 \mathrm{~nm}$ ), broadening of the interfaces will result. Variation in layer thickness is also expected between samples. Furthermore, there is a slight difference in SIMS sputter rates between the sputtered ZnTe layers and the CSS CdTe layer. Finally, in cases where data from multiple samples are plotted together, the depth scales have been shifted to align the maximum of the $\mathrm{Cu}$ signal near the $\mathrm{ZnTe} / \mathrm{CdTe}$ interface. Because of these issues, the interface locations shown on the figures are only rough estimates of the exact location.

Figure 1 compares two devices that have nominally identical contacts, except that the contact deposition temperatures are $100^{\circ} \mathrm{C}$ and $300^{\circ} \mathrm{C}$ (NP etching, $1.5-\mu \mathrm{m} \mathrm{ZnTe}$, $0.5-\mu \mathrm{m} \mathrm{ZnTe}: \mathrm{Cu}, 0.5-\mu \mathrm{m} \mathrm{Ni}$ ). At the $\mathrm{ZnTe}: \mathrm{Cu}$ outer surface (i.e., the surface that was the $\mathrm{Ni} / \mathrm{ZnTe}: \mathrm{Cu}$ interface prior to $\mathrm{Ni}$ removal), one sees that $\mathrm{Cu}$ is depleted and $\mathrm{Ni}$ diffuses inward at the higher temperature. Previous studies have shown that the lowresistance tunneling interface between the $\mathrm{Ni}$ and $\mathrm{ZnTe}: \mathrm{Cu}$ becomes more resistive when the $\mathrm{Cu}$ concentration in this layer falls below $\sim 4$ at.\%. Therefore, the $\mathrm{Cu}$ depletion may contribute to the "rollover" seen in stability studies of these devices.

Integration of the $\mathrm{Ni}$ signal in Figure 1 indicates that there is $\sim 6$ times more $\mathrm{Ni}$ for the contact deposited at $300^{\circ} \mathrm{C}$ compared to $100^{\circ} \mathrm{C}$. The increased $\mathrm{Ni}$ in the $\mathrm{ZnTe}$ bilayer supports the conclusion that diffusion of $\mathrm{Ni}$ from the outer metallization is occurring. The figure also shows a Ni signal at the $\mathrm{ZnTe} / \mathrm{CdTe}$ interface. At this time, the origin of this signal is uncertain because it also appears on devices contacted with Ti. As deposition temperature increases, $\mathrm{Cu}$ diffusion from the $\mathrm{ZnTe}: \mathrm{Cu}$ layer is seen to proceed through the $\mathrm{ZnTe}$ layer. A significant increase of $\mathrm{Cu}$ is generally observed in the (undoped) $\mathrm{ZnTe}$ layer, and this concentration increases further with deposition temperature. However, $\mathrm{Cu}$ diffusion does not proceed systematically into the $\mathrm{CdTe}$, but rather, builds up at the $\mathrm{ZnTe} / \mathrm{CdTe}$ interface. 

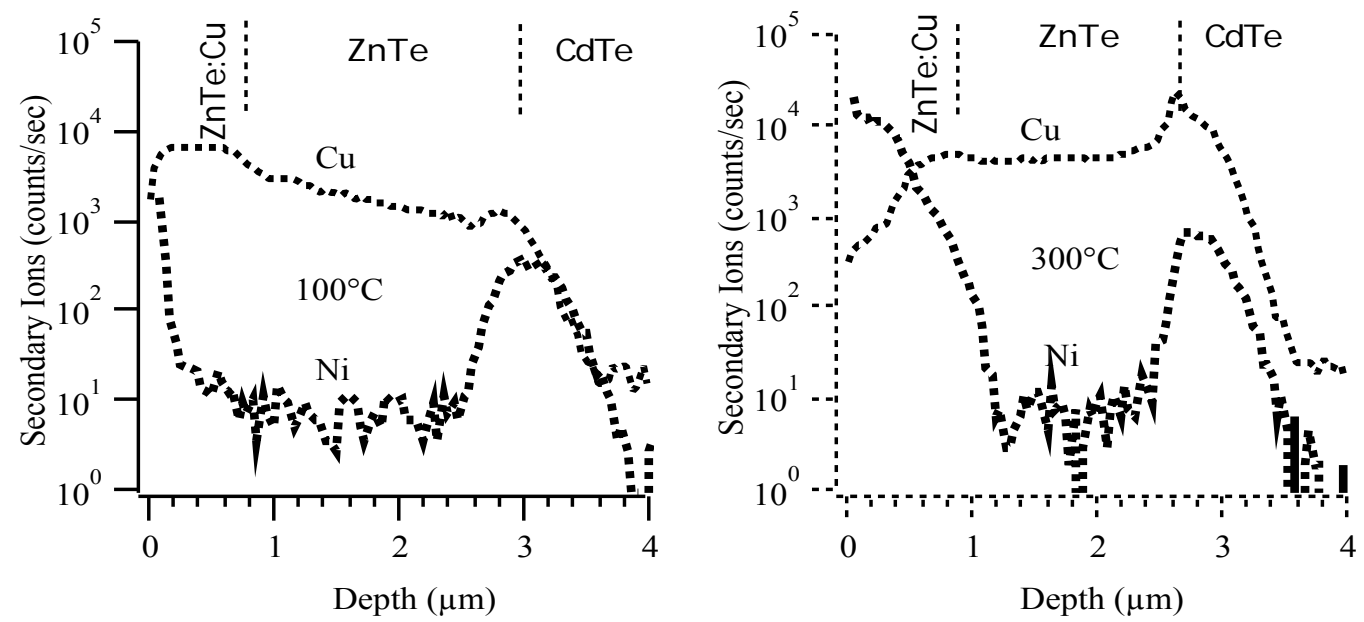

FIGURE 1. SIMS profiles showing effect of substrate temperature $\left(100^{\circ} \mathrm{C}\right.$ on left, $300^{\circ} \mathrm{C}$ on right $)$ on $\mathrm{Cu}$ and $\mathrm{Ni}$ diffusion.

Figure 2 compares $\mathrm{Cu}$ profiles from nominally identical contacts (NP etch, $300^{\circ} \mathrm{C}$, $0.5 \mu \mathrm{m} \mathrm{ZnTe}: \mathrm{Cu})$ except for the thickness of undoped $\mathrm{ZnTe}(0.4,0.8,1.5$, and 3.0 $\mu \mathrm{m})$. The figure also shows the $\mathrm{Cu}$ profile for a "control" device contacted with $\mathrm{Ni}$ (i.e., no $\mathrm{Cu}$ in the contact). The figure shows that $\mathrm{Cu}$ depletion at the metal/ZnTe:Cu interface persists, regardless of ZnTe thickness. Although the $\mathrm{Cu}$ buildup at the $\mathrm{ZnTe} / \mathrm{CdTe}$ interface decreases for a ZnTe thickness of $3.0 \mu \mathrm{m}$, the $\mathrm{Cu}$ concentration in the bulk CdTe is roughly equal that of the control device, regardless of $\mathrm{ZnTe}$ thicknesses. A peak in $\mathrm{Cu}$ concentration is observed near the $\mathrm{CdS}$ layer. Although this peak is observed even for the control device, it increases systematically as the $\mathrm{ZnTe}$ thickness decreases. The data suggest that the undoped ZnTe acts as a sink for $\mathrm{Cu}$ diffusion from the ZnTe:Cu layer and can limit the $\mathrm{Cu}$ buildup near the $\mathrm{CdS}$ layer. Although significant $\mathrm{Cu}$ diffusion from this contact is not observed in the CdTe, the $\mathrm{CdTe}$ layer may act as a conduit for $\mathrm{Cu}$ diffusion toward the $\mathrm{CdS}$ layer.
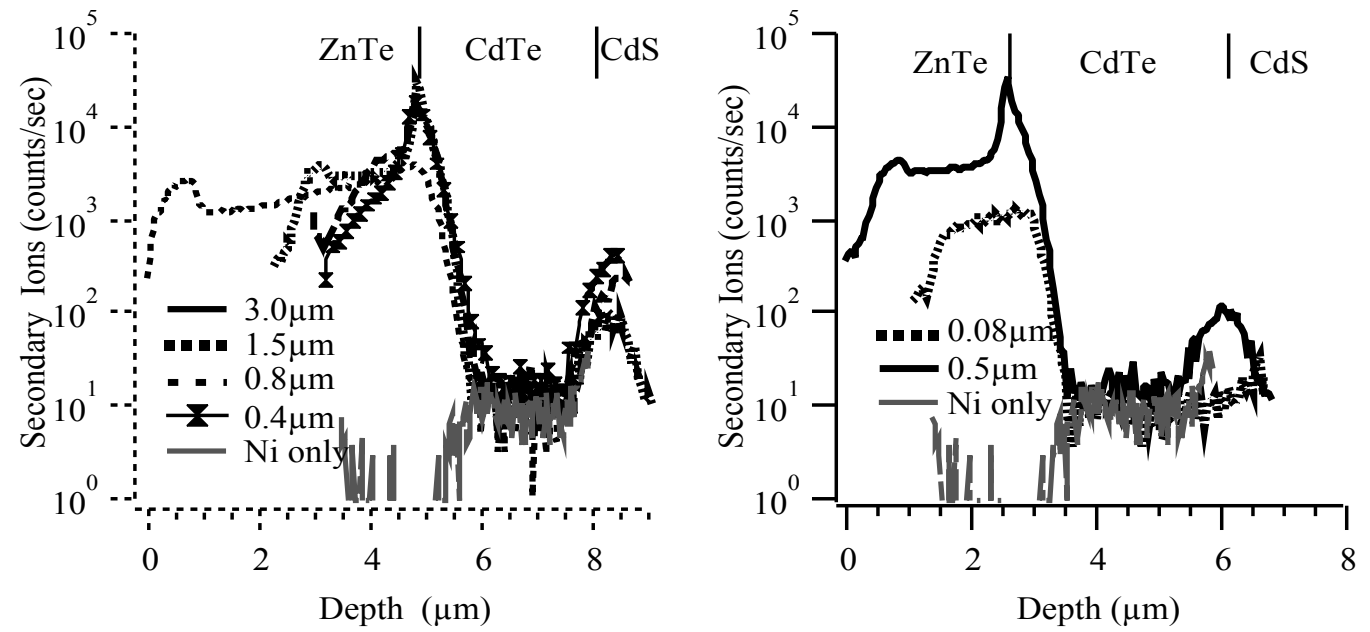

FIGURE 2. (Left) SIMS profiles showing the effect of undoped ZnTe layer thickness on $\mathrm{Cu}$ diffusion. The nominal thickness of undoped layer is indicated on figure.

FIGURE 3. (Right) SIMS profile showing effect of $\mathrm{ZnTe}: \mathrm{Cu}$ layer thickness on $\mathrm{Cu}$ diffusion. The nominal thickness of $\mathrm{ZnTe}: \mathrm{Cu}$ layer is indicated on figure. 
Figure 3 compares $\mathrm{Cu}$ profiles from nominally identical devices contacted with different thicknesses of $\mathrm{ZnTe}: \mathrm{Cu}(\mathrm{ZnTe}: \mathrm{Cu}=0.08$ and $0.5 \mu \mathrm{m}, \mathrm{ZnTe}=1.5 \mu \mathrm{m})$ and a control device contacted with $\mathrm{Ni}$ only. The figure shows that $\mathrm{Cu}$ diffusion through the $\mathrm{ZnTe}$ layer, and $\mathrm{Cu}$ buildup at the $\mathrm{ZnTe} / \mathrm{CdTe}$ interface, are present in both contacts. However, the concentration of $\mathrm{Cu}$ in the $\mathrm{ZnTe}$ layers is less for the contact with a thinner $\mathrm{ZnTe}: \mathrm{Cu}$ layer. Also, although the $\mathrm{Cu}$ concentration for both $\mathrm{Cu}$-containing contacts is roughly the same in the CdTe layer as in the control sample, the profiles show that the amount of $\mathrm{Cu}$ near the $\mathrm{CdS}$ layer is lower for the thinner $\mathrm{ZnTe}: \mathrm{Cu}$ layer.

Figure 4 compares $\mathrm{Cu}$ profiles from nominally identical devices contacted with $\mathrm{Ni}$ and Ti. For both these devices, the CdTe surface was ion-beam milled (rather than NP etched) prior to deposition of the $\mathrm{ZnTe}$ and metal layers. The figure also shows $\mathrm{Cu}$ profiles for an as-received device and a crystalline CdTe sample. Unlike previous profiles, these data are collected using high-mass resolution dynamic SIMS, and the two device profiles are plotted to align the outer $\mathrm{ZnTe}: \mathrm{Cu}$ interface. The figure illustrates that a significant difference between the metallizations is the absence of $\mathrm{Cu}$ depletion in the $\mathrm{ZnTe}: \mathrm{Cu}$ layer for the Ti contact. The difference in depletion may suggest why the Ti-contacted devices appear to suffer less from rollover of the I-V characteristics. Comparing the $\mathrm{Cu}$ concentration in the $\mathrm{CdTe}$ for the as-received device indicates an increase in $\mathrm{Cu}$ level caused by the back contact. Furthermore, although a peak in the $\mathrm{Cu}$ level is observed near the $\mathrm{CdS}$ layer for the as-received device, this peak increases significantly when the contact is added, supporting the observation mentioned earlier.

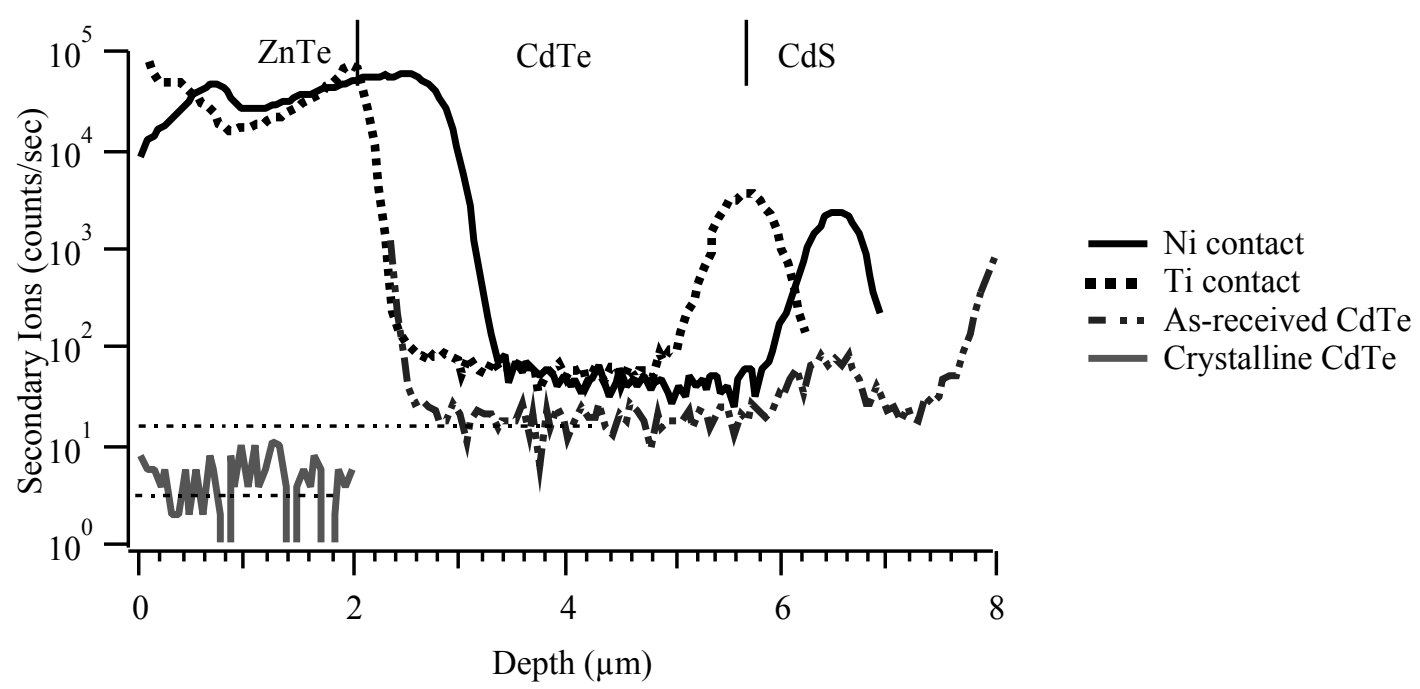

FIGURE 4. High-mass resolution SIMS profiles comparing the effect of Ni and Ti metallizations on $\mathrm{Cu}$ diffusion from the $\mathrm{ZnTe}$ contact. Figure also shows the SIMS-measured $\mathrm{Cu}$ concentration for a non-contacted CdTe device and a crystalline CdTe substrate. 


\section{CONCLUSIONS}

The ZnTe bilayer contact interface originally was developed assuming the presence of an undoped $\mathrm{ZnTe}$ layer between $\mathrm{ZnTe}: \mathrm{Cu}$ and the $\mathrm{CdTe}$ would control $\mathrm{Cu}$ diffusion into the CdTe and, thereby, improve device stability. We also assumed that the tunneling interface between the $\mathrm{ZnTe}: \mathrm{Cu}$ layer and the outer metallization would not be affected significantly by the particular type of metallization used. Using standard and high-mass resolution dynamic SIMS profiling of $\mathrm{Cu}$ diffusion from this contact, this study has investigated the extent to which these assumptions are correct.

When $\mathrm{Ni}$ is used as the outer metallization, $\mathrm{Cu}$ is depleted from the $\mathrm{ZnTe}: \mathrm{Cu}$ layer near the $\mathrm{ZnTe} /$ metal interface while Ni diffuses into the $\mathrm{ZnTe}$ layers. Cu depletion and $\mathrm{Ni}$ diffusion increase with increasing deposition temperature. Replacing Ni with $\mathrm{Ti}$ significantly reduces $\mathrm{Cu}$ depletion in the $\mathrm{ZnTe}: \mathrm{Cu}$ layer. A significant amount of temperature-dependent diffusion of $\mathrm{Cu}$ from the $\mathrm{ZnTe}: \mathrm{Cu}$ layer into the $\mathrm{ZnTe}$ layer is observed for both $\mathrm{Ni}$ and $\mathrm{Ti}$ metallizations. The $\mathrm{Cu}$ diffusion produces a build up of $\mathrm{Cu}$ at the $\mathrm{ZnTe} / \mathrm{CdTe}$ interface, but standard-resolution SIMS does not show increased $\mathrm{Cu}$ concentration in the $\mathrm{CdTe}$ layer. $\mathrm{Cu}$ concentration near the $\mathrm{CdS}$ layer increases when the thickness of the ZnTe:Cu increases, or when the thickness of the undoped $\mathrm{ZnTe}$ layer decreases. This suggests that the undoped ZnTe layer can act as a sink for $\mathrm{Cu}$ diffusing from the $\mathrm{ZnTe}: \mathrm{Cu}$ layer and that the $\mathrm{CdTe}$ may act as a conduit for $\mathrm{Cu}$ diffusion to the $\mathrm{CdTe} / \mathrm{CdS}$ junction region. High-mass resolution SIMS confirms the trends of increased $\mathrm{Cu}$ concentration near the CdS layer, and further reveals a slightly increased $\mathrm{Cu}$ concentration in CdTe relative to a non-contacted device. The types of $\mathrm{Cu}$ diffusion noted in this study provide insight into the mechanism of device instability observed in some $\mathrm{CdS} / \mathrm{CdTe}$ devices.

\section{ACKNOWLEDGEMENTS}

This work was supported by the U.S. Department of Energy under Contract \#DEAC36-83CH10093 and Subcontract \#ZAX-4-14013-01 (U. of Toledo). The assistance of R. Powell of SCI in supplying device material is gratefully acknowledged.

\section{REFERENCES}

1. Zweibel, K., Progress in Photovoltaics: Research and Applications, 3, 279-293 (1995).

2. Ponpon, J., Solid-State Electron., 28, 689-706 (1985).

3. Das, S.K. and Morris, G.C., J. Appl. Phys., 172, 4940 (1992).

4. Britt. J. and Ferekides, C., Appl. Phys. Lett., 62, 2851 (1993).

5. Rioux, D., Niles, D.W., and Hochst, H., J. Appl. Phys., 73, 8381-8385 (1993).

6. Gessert, T.A., Li, X., Coutts, T.J., Mason, A.R., and Matson, R.J., J. Vac. Sci. Technol. A, 12, 1501-1506 (1994).

7. Gessert. T.A., Sheldon, P., Li, X, Dunlavy, D., Niles, D., Sasala, R., Albright, S., and Zadler, B., Proceedings of the 26th IEEE Photovoltaics Specialists Conf., Piscataway, NJ., IEEE Press, 1997, pp. 419-422.

8. Chou, H.C., Rohatgi, A., Jokerst, N.M., Thomas, E.W., and Kamra, S., J. Electronic Mater., 24, 1093-1098 (1996).

9. Gessert, T.A., Mason, A.R., Reedy, R.C., Matson, R., Coutts, T.J., and Sheldon, P., J. of Electronic Materials, 24, 1443-1449 (1995). 